\title{
EL ARQUETIPO ICONOGRÁFICO DE LAS JERARQUÍAS ANGÉLICAS EN LA BAJA ANDALUCÍA DEL SIGLO XVIII
}

\section{THE ANGELIC HIERARCHIES ICONOGRAPHY IN $18^{\mathrm{TH}}$ CENTURY WEST ANDALOUSIA}

\author{
EsCARdiel GonZÁlez Estévez \\ Universidad de Sevilla. España \\ escardielge@gmail.com
}

\begin{abstract}
La jerarquía angélica, sistematizada por Pseudo Dionisio Areopagita desde el siglo V, no gozó de un amplio desarrollo iconográfico hasta la Baja Edad Media. En este estudio abordamos una codificación iconográfica surgida en Andalucía occidental en la primera mitad del siglo XVIII, partiendo de un grabado de 1713 incluido en el Trisagio especial devoto del capuchino fray Feliciano de Sevilla. Se analizan cinco lienzos inéditos ubicados en templos de Lebrija, El Puerto de Santa María, Sanlúcar de Barrameda y Arcos de la Frontera.

Palabras clave: jerarquías angélicas; iconografía; Cádiz; Pseudo Dionisio Areopagita; fray Feliciano de Sevilla.
\end{abstract}

The angelic hyerarchy, structured by Dionisus the Areopagite since $5^{\text {th }}$ century, did not have a wide iconographic development, however it can be seen in works, above all, from Late Medieval Age. In this paper, we dealt with an iconographic coding born in West Andalousia in the first half of $18^{\text {th }}$ century and based on a 1713 engraving included in the Capuchin Fray Feliciano de Sevilla's Trisagio especial devoto. We analyse five unknown paintings located in churchs in Lebrija, El Puerto de Santa María, Sanlúcar de Barrameda and Arcos de la Frontera.

Keywords: angelic hierarchies; iconography; Cadiz; Dionysius the Areopagite; Fray Feliciano de Sevilla.

\section{FUNDAMENTOS TEOLÓGICOS: LA CODIFICACIÓN DE PSEUDO DIONISIO AREOPAGITA}

Como sucede con cualquier faceta de la angelología, las Sagradas Escrituras son tremendamente parcas a la hora de exponer el asunto; no ofrecen una visión 
completa y ordenada; es más, resulta incluso contradictoria ${ }^{1}$. Ello obligó, como en muchos otros aspectos de la teología -especialmente, el mariológico-a que los exégetas del cristianismo construyeran un marco teológico que respondiera a los numerosos interrogantes sobre los ángeles: ¿cuántos y cómo eran?, ¿cuál era su ordenación y sus funciones?, ¿cuáles sus nombres?, ¿cómo podía comunicarse el fiel con ellos?, etc.

La patrística, atraída en pleno por el asunto, lo abordó desde la primera etapa y en todos sus focos: Alejandría, Asia Menor y Occidente. Desde San Ireneo, Orígenes, Clemente de Alejandría antes del siglo III; Epifanio y Dídimo el Ciego en el siglo IV; y, en la centuria siguiente, Teodoreto de Ciro, San Gregorio Magno o los capadocios y, muy especialmente, San Agustín. Notables precedentes que sucumben, no obstante, a la influencia de la demonología tradicional judía y neoplatónica, habida cuenta de la carencia de indicios en los textos bíblicos.

La misma tendencia sigue advirtiéndose en la primera obra cristiana dedicada en exclusiva al asunto: De coelesti Hierarchia, escrita hacia el siglo $\mathrm{V}^{2}$. Se demoró pues la teología cristiana primitiva en alumbrar una exégesis angelológica elaborada que pudiese rivalizar con la poderosa devoción popular a los ángeles, a pesar de que Pseudo Dionisio intentara ocultar la tardanza haciéndose pasar por el juez del Areópago convertido por San Pablo ${ }^{3}$. Ello puede entenderse como un intento por transferir autoridad a la obra y, probablemente, por desmarcarse de la herencia de la filosofía griega. Vano intento, sin embargo, pues la obra rezuma neoplatonismo en múltiples y destacados aspectos, como revela el esquema triádico de Proclo o la organización jerárquica de Plotino. Pseudo Dionisio explica que, conforme a la escala bíblica de Jacob, los ángeles transmiten a los hombres la iluminación que ellos mismos han recibido de las jerarquías superiores, estructuradas en tres ternas ${ }^{4}$. De esta manera, organiza nueve órdenes en tres coros: la primera jerarquía está formada por serafines, querubines y tronos; la segunda por dominaciones, virtudes y potestades; y la tercera por principados, arcángeles y ángeles.

${ }^{1}$ En el Antiguo Testamento, además de a los ángeles y a San Miguel, solo se menciona a querubines (Génesis 3, 24; Ezequiel, 1); sin embargo, en el Nuevo Testamento, junto a arcángeles (Tesalonicenses 4,15 ) y la numerosa presencia de ángeles, se menciona, por vez primera a tronos, dominaciones, principados y potestades en la Epístola a los Colosenses I, 15-16.

${ }^{2}$ PSEUDO DIONISIO AREOPAGITA: De coelesti hierarchia. París, 1970. Puede encontrarse una traducción española en MARTÍN, Teodoro H.: Obras completas del Pseudo Dionisio Areopagita. Madrid, 1990.

${ }^{3}$ VALEVA, Julia: "La tombe aux archanges de Sofia. Signification eschatologique et cosmogonique du décor", Cahiers archéologiques, 34, 1986, pp. 5-28.

${ }^{4}$ ROQUES, René: L'Univers Dionysien. Structure hiérarchique du monde selon le Pseudo-Denys. París, 1954. 
Este patrón, el primero en articular la nomenclatura de forma completa y orgánica, será el que guíe la concepción angelológica en lo venidero, con especial incidencia en la Alta Edad Media desde que el manuscrito fuese introducido en Occidente hacia el siglo IX ${ }^{5}$. No se recoge, sin embargo, ninguna mención expresa a los Siete Arcángeles; antes bien, los arcángeles, siempre genéricamente, son colocados en el penúltimo lugar de la jerarquía. Pero ello no será óbice para que el conjunto arcangélico se convierta en el más relevante y definido de toda la jerarquía, como demuestra el lugar protagónico que ostentan en el arquetipo iconográfico que aquí se estudia.

De esta forma, podrá rastrearse la huella pseudo dionisiana sobre el monaquismo románico, en las tres corrientes principales: la escuela cisterciense, los cartujos y las visionarias alemanas ${ }^{6}$. Aunque los cartujos fueron considerados los imitadores de la condición angélica por antonomasia, los textos más destacados proceden de otros focos. Así, el De Consideratione de San Bernardo de Claraval, elabora su doctrina: una propuesta de imitación del ángel para los cistercienses. Más relevancia posee el Scivias (I, 6) de Hildegarda de Bingen, con aportaciones destacadas en cuanto a la clasificación jerárquica que innovan en el ordenamiento de los coros frente a lo expuesto por el Areopagita ${ }^{7}$. Aunque manteniendo los nueve coros, los distribuye en acies -formaciones de batalla-con un esquema 2,5,2 que inserta en tres coronas. Santo Tomás de Aquino cerrará el periodo medieval con la sistematización más completa hasta entonces de la angelología en la primera parte de la Summa; no en vano, es conocido como el Doctor Angelicus.

\section{UNA COMPLEJA TRADUCCIÓN VISUAL: LAS JERARQUÍAS ANGÉLICAS EN LA TRADICIÓN ICONOGRÁFICA CRISTIANA}

De nuevo, la parquedad de los textos testamentarios hacia los ángeles dificultó una concreción visual temprana. No se señalan atributos, ni siquiera alas,

${ }^{5}$ El manuscrito fue enviado por el emperador bizantino Miguel el Tartamudo a su homólogo occidental, Luis el Piadoso, en el año 827, conservándose en el monasterio de Saint Denis. Juan Escoto Erígena lo traduce al latín, tras un intento anterior bastante defectuoso, y Hugo de San Víctor hará lo mismo hacia 1135 en el contexto del Renacimiento carolingio. Gozará de una enorme influencia no solo en los círculos teológicos, sino en los medios místicos como el de las beguinas cistercienses, renovando el tradicional tema monástico de la imitación de los ángeles. Véase FAURE, Philippe: "Denys, le Pseudo-Aréopagite et le moyen age occidental: réception et influence de la Hierarchie céléste", Les Cahiers de Saint Michel de Cuxá, 28, 1997, pp. 213-216.

${ }^{6}$ STAPERT, Aurelia: L'ange roman dans la pensée et dans l'art. París, 1975.

${ }^{7}$ De las tres partes que conforman el Scivias, la primera se refiere a la Creación desplegando seis visiones. La sexta y última trata sobre la creación y ordenamiento de los coros angélicos. 
de manera tal que las figuras de los ángeles anteriores al siglo IV no tienen una iconografía precisa. A ello se sumaba otro problema: la naturaleza incorpórea de los ángeles, lo cual complicaba, a priori, su representación visual ${ }^{8}$.

En sus primeras representaciones sobre las catacumbas romanas desde fines del siglo II, los ángeles son ápteros, es decir, parecen humanos, difícilmente diferenciables de estos ${ }^{9}$. Siempre masculinos, pueden oscilar en su edad, aunque el aspecto habitual es el de jóvenes imberbes -muy raramente presentan barba-. La indumentaria es la habitual de la época: túnica larga y pallium, propio de los orantes, o dalmática ${ }^{10}$. Si para la concepción angélica se acudió al sustrato persa, para la iconografía será el arte grecorromano quien ofrezca el sustento. Así, en la necesidad por definir su imaginería, el cristianismo echa mano de la riqueza iconográfica clásica, asumiendo el patrón de los genios alados y las nikés de la Baja Antigüedad, provistos ambos de alas. Estas se convertirán a partir del siglo V en el atributo angélico por antonomasia y emblema del vuelo. La lentitud en adoptar la iconografía parece responder al deseo de descartar del embrionario arte cristiano una tipología que habría podido recordar en exceso a figuras paganas y, por tanto, resultar peligrosa.

Finalmente, la concreción visual de los arcángeles se realizó en base a la vestimenta imperial -túnica, clámide, sandalias y loros--, portando cetro y globo; es decir, su imagen evocaba la de un emperador, solo diferenciable de este por las alas y, a veces, por el nimbo ${ }^{11}$. El cosmocrator se erige así en la tipología principal y más temprana para representar a los arcángeles en Bizancio. Esta codificación será la que absorberá la Edad Media, trasvasándose desde Bizancio al nuevo mundo occidental que, en sus sucesivos renacimientos a partir de Carlomagno, irá incorporando la iconografía angélica: desde los marfiles carolingios, cuando lo oriental es aún tan acusado, hasta las portadas de las grandes catedrales góticas que anuncian la sensibilidad renacentista, pasando por los esmaltes o los capiteles de los monasterios románicos ${ }^{12}$.

Las jerarquías angélicas se vieron afectadas, más si cabe, por esta balbuceante indefinición. El tema nunca fue motivo de protagonismo único, sino que, más

\footnotetext{
8 PEERS, Glenn: Subtle bodies: representing angels in Byzantium. Berkeley, 2001.

9 BUSSAGLI, Marco: Storia degli angeli, racconto di immagini e di idee. Milano, 1991, pp. 45-58.

10 ESTIVILL, Daniel E.: La imagen del ángel en la Roma del siglo IV. Estudio de iconología. Roma, 1994.

${ }^{11}$ DIEGO BARRADO, Lourdes: "Le rôle des anges dans l'iconographie de la Rome byzantine", Cahiers de Saint Michel de Cuxa, 28, 1997, pp. 133-144.

12 Véase para el periodo altomedieval el aquilatado trabajo de STAPERT, Aurelia: L'ange dans la pensée..., op. cit. Y, para la transición entre la Baja Edad Media y el Renacimiento, el capítulo dedicado a los ángeles en el clásico tratado de KÜNSTLE, Karl: Ikonographie der Christlichen Kunst. Friburgo, 1928, pp. 239-264.
} 
bien, se vieron abocadas a un segundo plano, acompañando a algunos personajes bíblicos, especialmente, la Trinidad o María, y prodigándose en determinadas escenas glorificadoras, u otras como el Juicio Final. En los casos aquí tratados constituyen lienzos, un formato aún más extraño, si cabe, a la tradición representativa del tema, el cual estaba más enfocado a revestimientos murarios, sobre todo, en las alturas de los templos.

Excepto para querubines, serafines y ángeles, resulta difícil encontrar características específicas para ser adoptadas como sistema de reconocimiento entre los restantes coros. Marco Bussagli, en su estudio cotejado sobre los primeros ejemplos del asunto en Italia entre los siglos XIII y XIV (los baptisterios de las catedrales de Venecia y Florencia, ambos musivarios, y el ciclo pictórico de la capilla Carrarese de Padua) demuestra la ausencia de una tradición rigurosamente codificada. Esta es la causa, junto a la revolución iconográfica del Juicio miguelangelesco, según el autor, de una sustancial simplificación iconográfica que aqueja a los lienzos dieciochescos aquí tratados ${ }^{13}$.

La cultura artística del norte de Europa sí desarrolló una visión más puntualizada de los nueve coros, incluso en la Edad Moderna ${ }^{14}$. Aparece en las arquivoltas de los pórticos del Gótico francés, como en la Sainte Chapelle de Vincennes, en vidrieras inglesas (priorato de Great Malvern, Worcestershire), o en ciclos pictóricos en Centro Europa (abadía de Klosterneuburg, Viena) ${ }^{15}$. Pero será la miniatura el formato y técnica que de una forma mayoritaria, y más temprana, acogerá la iconografía con ejemplos señeros como el Cantar de los Cantares de Bamberg (siglo XI), la Vida de San Dionisio (ca. 1317), el Salterio Queen Mary (siglo XIV) $\mathrm{y}$, especialmente, las distintas versiones en forma concéntrica del Scivias de Hildegarda de Bingen, la visionaria alemana que profundizó en la clasificación dionisiana ${ }^{16}$. En territorio ibérico no se han conservado, sin embargo, imágenes, ni medievales, ni posteriores.

El Renacimiento italiano elaboró otra codificación, contenida en un grabado incluido en el libro del siciliano Antonio Duca: Septem principem angelorum, publicado en Nápoles en 1594, que poco tiene que ver con sus precedentes italianos ${ }^{17}$

13 BUSSAGLI, Marco: Storia degli angeli..., op. cit.

${ }^{14}$ WIRTH, Karl-August: Reallexikon zur deustschen Kunstgeschichte. Stuttgart, 1967, col. 555-601 (Engelcöre). Véase también PAUKER, Wolfgang: "Der marianische Bildercyclus des Stiftes Klosterneuburg. Eine ikonographische Studie", Berichte und Mittheilungen des Alterthums-Vereines zu Wien, 35, 1900, pp. 1-32.

15 RÉAU, Louis: Iconografía del arte cristiano. T. 1, vol. 1. Barcelona, 1996, pp. 62-65.

${ }^{16}$ GARCÍA MAHÍQUES, Rafael: "Las jerarquías celestes", en GARCÍA MAHÍQUES, Rafael (dir.): Los tipos iconográficos de la tradición cristiana. T. 2, vol. 1. Madrid, 2016, pp. 230-255.

17 DUCA, Antonio: Septem principem angelorum orationes cum antiquis imaginibus opera Antonii Ducae presbitero Cephaludensis olim editae. Nápoles, 1594. La imagen es una 
(Figura 1). La composición organiza en tres planos superpuestos a los tres grupos de seres alados, identificados por una inscripción. Se ha pretendido codificar a cada conjunto con un rasgo característico; así, en orden de izquierda a derecha, y de arriba a abajo, se aprecian: los principados con coronas, los arcángeles con balanzas, los ángeles portando pequeñas figuras humanas para significar su protección sobre las almas, las dominaciones con cetros, las virtudes sosteniendo orbes, las potestades armadas con lanzas y protegidas con petos y yelmos, los serafines sosteniendo corazones, los querubines cantando frente a sus libros y, para los tronos, se ha colocado un gran sitial vacío. Por encima, los arcángeles, no arrodillados, sino en pie, se distribuyen con Miguel, Uriel y Rafael a la derecha, mientras que Gabriel, Jehudiel, Sealtiel y Barachiel lo hacen en el lado frontero. Y coronando, la Santísima Trinidad, sin olvidar a la Virgen.

Siguiendo los trazos de la Trinidad, parte un haz que llega a la parte inferior, donde se representa un grupo de árboles sobre el agua, encerrados en una plaza donde se inscribe el "Alleluia, Alleluia". Ello puede estar relacionado con el versículo de $J o b 38,7$, inscrito en la parte inferior, y que puede traducirse como "Mientras que me alababan los nacientes astros, y prorrumpían en voces de júbilo todos los hijos de Dios", que son las palabras dichas por Dios a Job en el primer discurso, para poner de manifiesto el contraste entre Dios y el hombre.

La inclusión de esta imagen en un libro, le proporcionaba un trampolín para su difusión; sin embargo, no influyó sobre la clasificación visual de los lienzos dieciochescos, a pesar de que nos consta la circulación del libro en la península. En América, donde no hemos podido verificar la presencia del libro, sí se produce una influencia, como demuestra el lienzo del beaterio de Nazarenas en el Cuzco ${ }^{18}$.

Ante la ausencia de una tradición ibérica en la representación de los coros angélicos y el relegamiento general, a partir del Renacimiento, sorprende tanto más este florecimiento de la iconografía que experimenta el área bajoandaluza en el siglo XVIII ${ }^{19}$.

calcografía anónima $(13$ x $11 \mathrm{~cm})$ que examinamos en el ejemplar de la Biblioteca della Società Napoletana di Storia Patria.

${ }_{18}$ Los coros acompañan la Coronación de la Virgen en este lienzo anónimo de mediados del siglo XVIII. Véase MÚJICA PINILLA, Ramón: Ángeles apócrifos en la América virreinal. México, 1999, lám. 9.

${ }^{19}$ Hemos optado por la demarcación geográfica "Baja Andalucía" por considerarla más pertinente y menos anacrónica que la de la actual provincia de Cádiz, donde se encuentran cuatro de los cinco lienzos analizados. En la época en que estas imágenes se producen, tales poblaciones pertenecen a la antigua demarcación eclesiástica hispalense. Véase CANO GARCÍA, Gabriel: Divisiones territoriales y comarcalizaciones en Andalucía. Pasado y Presente, en Geografía económica de Andalucía, vol. VII, Madrid, 1990, pp. 23-90. 


\section{EL ARQUETIPO DE LAS JERARQUÍAS ANGÉLICAS EN LA BAJA ANDALUCÍA: EL GRABADO DE FRAY FELICIANO DE SEVILLA Y SU TRASLACIÓN PICTÓRICA}

Este trabajo analiza cinco anónimos $\operatorname{lienzos}^{20}$ fechables a mediados del siglo XVIII y ubicados en templos de Lebrija ${ }^{21}$ (Figura 4), El Puerto de Santa María ${ }^{22}$ (Figuras 5-6), Sanlúcar de Barrameda ${ }^{23}$ (Figura 3) y Arcos de la Frontera ${ }^{24}$ (Figura 7). Todos siguen un mismo patrón para representar la Jerarquía angélica: los nueve coros son distribuidos en dos columnas, cinco a la izquierda, y cuatro a la derecha, presididos por los Siete Príncipes de los Ángeles en la parte superior. Una filacteria a los pies identifica a cada grupo (Figura 8). En la mayoría de los casos, la composición está rematada por la escena de la Coronación de la Virgen -a veces, con San José a un costado-, o la Trinidad; mientras que, en otros, se incluye en la parte inferior un monje franciscano arrodillado, o un ángel con un niño, en ambos casos, alzando la vista con ademán extasiado. El lienzo de Arcos de la Frontera establece una mayor distancia respecto a los cuatro restantes, al perderse la unidad de los grupos, aquí menos homogeneizados, y sin las filacterias. La diferencia más notable respecto a la codificación en este caso es que los Siete Príncipes no se instalan presidiendo las dos columnas, sino que lo hacen, con Miguel al centro de los querubines, y los restantes flanqueando a la Trinidad, de tal manera que ahora las dos columnas de ángeles sí resultan equilibradas con cuatro coros a cada lado.

Atendiendo a la ordenación pseudo dionisiana, la colocación de cada grupo responde a un trayecto visual en zigzag que comienza con los serafines en el grupo superior izquierdo y termina en los ángeles en el grupo inferior izquierdo. Los

${ }^{20}$ No profundizaremos aquí en los aspectos formales de las obras, centrados como estamos en el asunto iconográfico. Se ofrecerán unos mínimos datos catalográficos en nota al calce de forma particularizada a continuación. No hemos tenido la fortuna de encontrar referencias a tales obras en la literatura periegética o en la historiografía local más o menos actual, siendo desatendidas por la investigación quizá por considerarse de menor interés a nivel artístico.

${ }^{21}$ Templo del convento de San Francisco (lado de la epístola, a los pies), Lebrija, óleo sobre lienzo, 132 × $94 \mathrm{~cm}$.

${ }^{22}$ Capilla de la Aurora (lado de la epístola, a los pies), El Puerto de Santa María, óleo sobre lienzo, 129 x $98 \mathrm{~cm}$. El otro lienzo adscrito a esta localidad se encuentra actualmente en paradero desconocido (previamente, capilla de la Aurora, El Puerto de Santa María), óleo sobre lienzo (medidas desconocidas), 1748, con la inscripción: "Se hizo a devoción de Dn. Antonio Fernández Presb. ${ }^{\circ}$ Año de 1748”, fotografía del Archivo Mas.

${ }^{23}$ Templo de San Nicolás de Bari (lado de la epístola, a los pies), Sanlúcar de Barrameda (aunque procedente del templo de San Francisco en la misma localidad), óleo sobre lienzo, 121 x $82 \mathrm{~cm}$.

${ }^{24}$ Templo de San Francisco (lado de la epístola, al centro), Arcos de la Frontera, óleo sobre lienzo, 135 x $99 \mathrm{~cm}$. 
integrantes de cada colectivo - entre cuatro y seis, según el lienzo-, confluyen direccionalmente hacia el interior, quedando enfrentados, y el ángel que preside la marcha aparece dotado con bastón de mando y morrión emplumado. El ejemplar de Arcos de la Frontera, sin embargo, coloca a una figura destacada en el centro de cada coro, en este caso, con atuendo más monárquico que militar, pues aparecen dotados de corona y capa. Por su parte, los "Siete Espíritus que asisten delante de Dios", como recoge la filacteria, se identifican con los Siete Arcángeles de Palermo ${ }^{25}$ según revelan sus atributos y, en el ejemplar de Sanlúcar de Barrameda, también sus nombres -borrados, pero aún perceptibles, en el caso de los apócrifos-. De esta manera, Miguel, flanqueado por Rafael y Gabriel, es acompañado por Jehudiel -corona y flagelo-y Barachiel -rosas en el manto- a la derecha, y por Uriel - espada- y Sealtiel - espejo y linterna- a la izquierda, apuntando así el influjo de la matriz italiana; y, curiosamente, todos llevan, además, cetros, para señalar su superior jerarquía.

La diferenciación de cada coro se realiza en base al atuendo, más bien, al cromatismo del atuendo; pero raramente ajustándose a la parca descripción escriturística o a la escasamente definida tradición iconográfica. Todos son representados como ángeles, con una versión casi imperceptible del carácter multialado que provee la descripción bíblica y que encontramos en algunas pinturas medievales en querubines o serafines, y sin rastro de alas oceladas. De esta manera, todos visten túnicas con lazos, excepto las potestades que portan armadura. La coincidencia de colores, rojo para principados y dominaciones, blanco para querubines, azul para tronos..., así como la ordenación evidencian una circulación del mismo modelo a través de copias pictóricas.

El origen de esta codificación visual se sitúa en una xilografía incluida en el libro del capuchino fray Feliciano de Sevilla Trisagio especial devoto, publicado en $1713^{26}$ (Figura 2). El sumario grabado publicado para introducir la parte relativa a los Príncipes del Empíreo, que configura una de las tres partes de la obra, responde a la misma codificación que ya se ha expuesto aquí para los lienzos tratados: los nueve coros distribuidos en dos columnas y presididos por los Siete Príncipes. A los pies, aparece un capuchino genuflexo, en clara alusión al autor, alzando la vista y con los brazos extendidos en señal de arrobo ante tan beatífica visión, como ocurre en el ejemplar de El Puerto de Santa María.

${ }^{25}$ Véase GONZÁLEZ ESTÉVEZ, Escardiel: "De fervor regio a piedad virreinal. Culto e iconografía de los Siete Arcángeles”, Sémata, 24, 2012, pp. 111-132.

${ }^{26}$ DE SEVILLA, Fray Feliciano: Trisagio especial devoto acerca de la estupenda Excelencia, e importancia de tres especialísimas devociones. La primera, de la Suprema y Beatissima Trinidad, La Segunda de las Cinco Preciossisimas Llagas de Christo S. N., y la tercera, de los preexcelentes príncipes del Empyreo. Sevilla, post quem 1713, p. 225. s. f. Se trata de un anónimo grabado xilográfico a toda plana $(12 \times 6 \mathrm{~cm})$, consultado en el ejemplar que custodia la Biblioteca Diocesana de Córdoba, el único que hemos podido localizar. 
La vida de fray Feliciano de Sevilla transcurrió entre Sevilla y Granada, donde murió en $1722^{27}$, destacando las fuentes su devoción a los ángeles y a la Santísima Trinidad y su incansable celo por la evangelización, pues, como bien dice Henry Kamen, "en España no eran menores las 'Indias' de no creyentes que las que había en el Nuevo Mundo" 28 . Su acendrada devoción angélica es expresada con vehemencia en la carta que dejó escrita antes de su muerte a sus hermanos capuchinos ${ }^{29}$ : “Ángeles santos, mis señores, queridos de todo mi corazón y amigos míos. Ahora es la ocasión, en que se ha de ver lo mucho que valéis a favor de vuestros devotos. Bien sabéis, que fiados en vuestro patrocinio, jamás he tenido miedo a los demonios" $" 30$.

El capuchino aparejó a su encomiable labor misional una profusa producción literaria en la que el asunto angélico se repite adquiriendo un lugar connotado ${ }^{31}$. Entre las obras dedicadas, tres versan sobre los ángeles ${ }^{32}$, abordándose el tema junto a la Trinidad y las Cinco Llagas en el Trisagio especial devoto.

${ }^{27}$ AMS (Archivo Municipal de Sevilla), sección especial siglo XVIII, Testamentaría del Señor Conde del Águila, G, t. 13. 22a, "Memorias del venerable P. fray Feliciano de Sevilla". Véase también DE SEVILLA, Fray Pedro José: Gritos de un capuchino enfermo a todos los predicadores del orbe... carta manuscrita al Excmo Señor D. Juan Camargo... Obispo de Pamplona. Sevilla, 1724, pp. 76-92.

${ }_{28}$ KAMEN, Henry: La Inquisición española: una revisión histórica. Barcelona, 1996, p. 248.

${ }^{29}$ DE MÁLAGA, Fray Felipe: Noticia del feliz tránsito de fray Feliciano de Sevilla, misionero apostólico. Valladolid, 1722, p. 7. Tras una breve introducción, se adjunta el "Manifiesto que dexo en su muerte escrito el V. P. Fray Feliciano para todos sus conventos", que es, ante todo, una apología de la labor misionera frente a la vía contemplativa y una arenga a sus hermanos para que elijan tal camino. Ya se ocupó de ensalzarlo DE MÁLAGA, Fray Felipe: Luz apostólica, que demuestra la gran excelencia e importancia de el altissimo y divinissimo exercicio de la Santa Mission y de como esta se ha de practicar con especial fruto. Sevilla, 1716.

${ }^{30}$ DE MÁlAGA, Fray Felipe: Luz apostólica..., op. cit., p. 16. Continúa pidiendo en la hora de su muerte a San Miguel "una poderosísima guardia de nueve mil espíritus angélicos de cada coro de los nueve [...] Y no piensen que me excedo en pedir, que según el concepto, que tengo de V. Alteza Real, de vuestro gran poder, de vuestra gran caridad, especialmente, para los que de ti se valen, ninguna deuda me queda de tan glorioso efecto".

${ }^{31}$ Posee una decena de obras, entre las cuales tres se dedican a la Trinidad, dos a María, una a las Ánimas del Purgatorio, una a las misiones y tres a la materia angélica.

${ }^{32}$ DE SEVILLA, Fray Feliciano: Antorcha angelical en honra de los Santos Ángeles, con algunos exercicios de su especial culto, entre ellos su novena... La da a la luz el P. Fray Luis Lascano del Real y Militar Orden de Nra. Sra. de la Merced, y la dedica junto con su corazón a estos Novilissimos Principes del Empyreo. México, 1758. Se reeditó en 1771. 
En Los Angélicos Príncipes del Empyreo ${ }^{33}$, dividido en cuatro libros como señala el título completo, el autor se queja del olvido que sufren los ángeles en España y en el mundo ${ }^{34} \mathrm{y}$, ante ello, insta a que "los predicadores exhorten a la devoción de estos siete Ángeles, que los Padres de familia [religiosa] hagan pintar y tengan en sus casas imágenes de estos siete príncipes [...] y a ti, católico lector, [...] que erigieras tú en tu patria, o en otra parte un templo de ellos que sirviera de despertador - como en Palermo- a tantos, como los tienen olvidados" ${ }^{35}$.

Insistirá más adelante en ello, dedicando un capítulo al ejercicio de "Tener pintadas para su veneración sus imágenes" 36 , tanto en sitios públicos como priva$\operatorname{dos}^{37}$. Este fue empeño que fray Feliciano no descuidó en sus misiones, a tal punto que no quedó una sin "plantar" esta devoción, calculando el autor que "de entonces habrán quedado más de medio millón de devotos"38. Tal tesón será corroborado por otras fuentes, que nos relatan la erección de retablos en las misiones ${ }^{39}$.

Parece que el exhorto de fray Feliciano incidió sobre algunos centros andaluces, si no propiamente capuchinos, sí franciscanos ${ }^{40}$, que adoptaron el grabado de las Jerarquías llevándolo a la pintura de forma más completa. La concentración de los lienzos en cuatro poblaciones de Andalucía occidental, comprendidas entre las actuales provincias de Sevilla y Cádiz: Lebrija, Sanlúcar de Barrameda, el Puerto de Santa María y Arcos de las Frontera, indica una focalización en la zona que ha de vincularse con el origen del fraile capuchino, aunque sorprende que no se produjera un desarrollo similar en el área más próxima a la capital sevillana o en el área granadina, donde fundamentalmente desarrolló su actividad. Quizá la causa de tal ausencia estribe en los aciagos acontecimientos que afec-

${ }^{33}$ DE SEVILLA, Fray Feliciano: Los Angélicos Príncipes del Empyreo, quantas y quales sean sus Excelencias. Quantos y quales los Beneficios, que nos hacen. A que personas se esmeran asistir y favorecer mas. De que modo los obsequiaremos, y obligaremos mucho. Sevilla, 1711. El grueso de las citas se apoya sobre la experiencia monástica femenina, y es que el afecto de estas a lo angélico fue cultivado desde antiguo e inflamado en estos años. Así leemos experiencias de Santa Brígida, Santa María Magdalena de Pazzi, Mariana de Escobar o sor María de Agreda.

${ }^{34}$ Ibidem, lib. II, cap. VI, punto 2, p. 206.

${ }^{35}$ Ibid., lib. II, cap. VII, punto 13, p. 237.

${ }^{36}$ Ibid., lib. IV, cap. IV, pp. 532-536.

37 Ibid., p. 533.

${ }^{38}$ Ibid., lib. III, cap. III, punto 14, p. 390.

39 DE MÁLAGA, Fray Felipe: Noticia..., op. cit., pp. 5-6. "Porque no faltase testimonio de su pureza y cordial devoción a los Santos Ángeles a quienes erigía retablos en las misiones y en fomento de su devoción escribió libros".

${ }^{40}$ Las pinturas -salvo la ahora en paradero desconocido de El Puerto-se localizan en templos, tres de ellas, pertenecientes a los franciscanos, o de procedencia de estos, como en el caso del lienzo de Sanlúcar de Barrameda, del que, por testimonios orales, se sabe que procede de la iglesia de San Francisco de la misma localidad gaditana. 
taron a la destrucción del patrimonio en los siglos XIX y XX, donde los centros franciscanos y capuchinos sufrieron especialmente en Sevilla. En cualquier caso y a pesar de esta ausencia de obras similares en centros capuchinos en la actualidad, resulta pertinente plantear que fue fray Feliciano, a través de su actividad misional y sus textos, quien impulsó la difusión de este arquetipo, aunque desconozcamos las circunstancias concretas que radican en la comisión de cada una de estas imágenes. Solo tenemos datos para el lienzo, hoy en paradero desconocido, procedente de la capilla de la Aurora, en el Puerto de Santa María. Gracias a una inscripción inferior podemos conocer la cronología concreta y su comitente: "Se hizo a devoción de Dn. Antonio Fernández, presb. ${ }^{\circ}$ Año de 1748”. El encargo, en este caso, no se vincula a ningún miembro perteneciente a la rama seráfica o capuchina, aunque quizá existiera relación con este presbítero, del que nada más hemos logrado saber. La cronología evidencia un desarrollo ciertamente posterior a la publicación del grabado (1713), dando pie a datar los restantes lienzos hacia los comedios de la centuria, junto a otras razones de estilo. Nada sabemos tampoco acerca de la autoría, ni tampoco es posible ni el más mínimo atisbo de atribución, si quiera a un círculo, tratándose de una labor pictórica, casi más cercana a la miniatura.

Los cinco lienzos estudiados -quizá más en el futuro-, junto al grabado, ponen de manifiesto la plasmación visual de un complejo asunto teológico que se desmarca de la tradición iconográfica previa, para alumbrar una codificación novedosa en territorio andaluz durante el siglo XVIII ${ }^{41}$.

Fecha de recepción: 22 de octubre de 2017

Fecha de aceptación: 12 de abril de 2018

${ }^{41}$ Agradezco a mi compañero, el profesor Pedro M. Martínez Lara, las fotografías de los lienzos que se incluyen aquí, no solo por tomarlas, con su sabiduría fotográfica, sino por acompañarme a los distintos templos. Al profesor Enrique Valdivieso le debo la fotografía del Archivo Mas y el conocimiento del desaparecido lienzo que se encontraba en la capilla de la Aurora y ahora, por desgracia, está en paradero desconocido. En Lebrija, tengo que agradecer a mi compañero el licenciado Juan de Dios Doblado Velázquez el aviso y las gestiones para tomar la fotografía en San Francisco; en El Puerto de Santa María, a Francisco Jesús Rodríguez González, siempre dispuesto a mis requerimientos en la capilla de la Aurora, hoy sede de la Hermandad de la Humildad y Paciencia; y en Sanlúcar, al profesor Fernando Cruz Isidoro, quien acogió mi propuesta para presentar una primera aproximación sobre el tema que aquí analizamos en las IV Jornadas de investigación sanluqueña, la Sanlúcar imaginada, que él organizó en 2014. 




Figura 1. Anónimo, Jerarquía angélica con los Siete Arcángeles como principales, 1594, en DUCA, Antonio: Septem principem angelorum... Nápoles, 1594.

LABORATORIO DE ARTE 30 (2018), pp. 243-260, ISSN 1130-5762 e-ISSN 2253-8305 - DOI http://dx.doi.org/10.12795/LA.2018.i30.13 


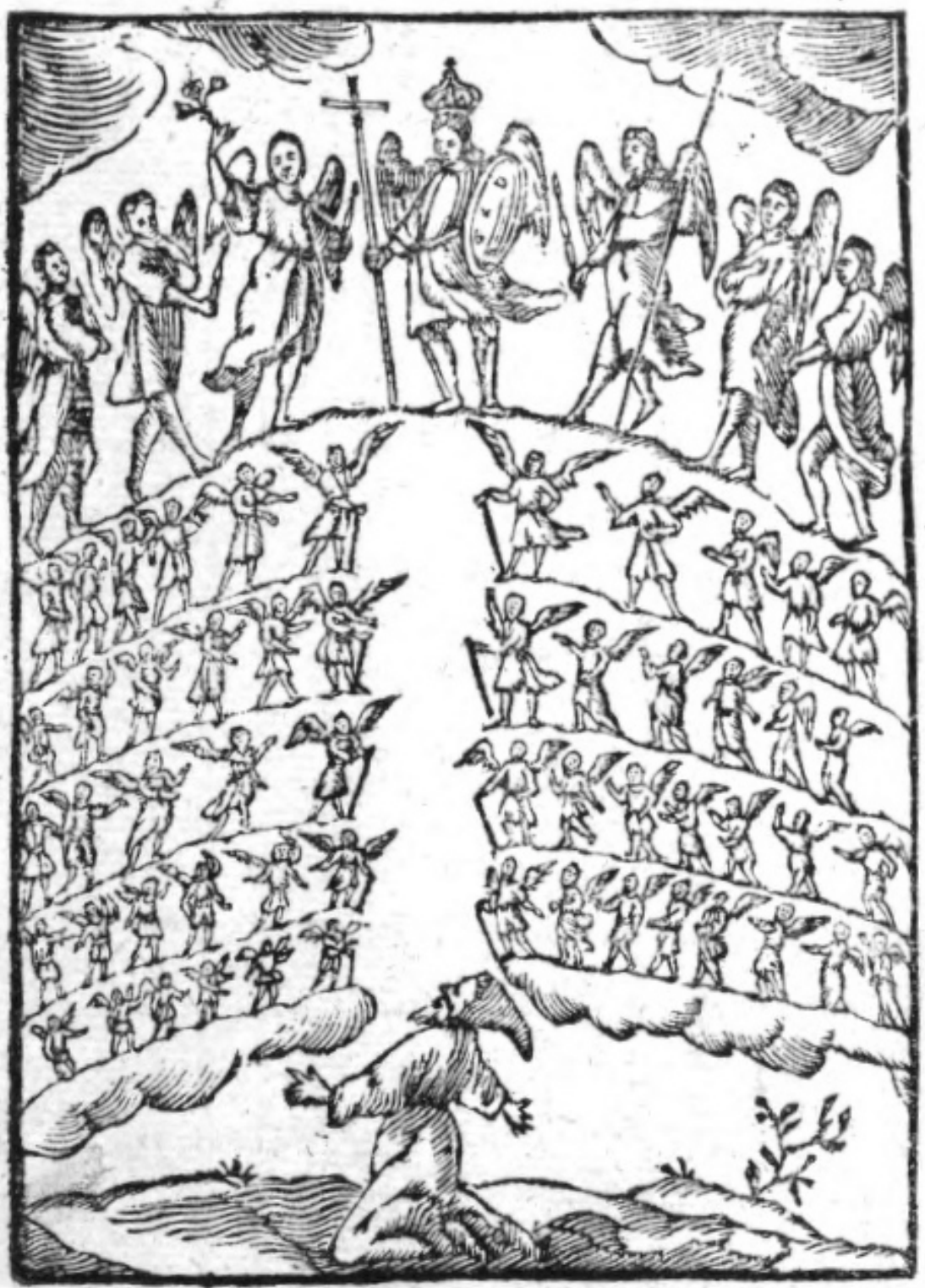

Figura 2. Anónimo, Jerarquía angélica con los Siete Arcángeles como principales en la visión de Fray Feliciano, 1713, en DE SEVILLA, Fray Feliciano: Trisagio especial devoto... Sevilla, post quem 1713, p. 225. 


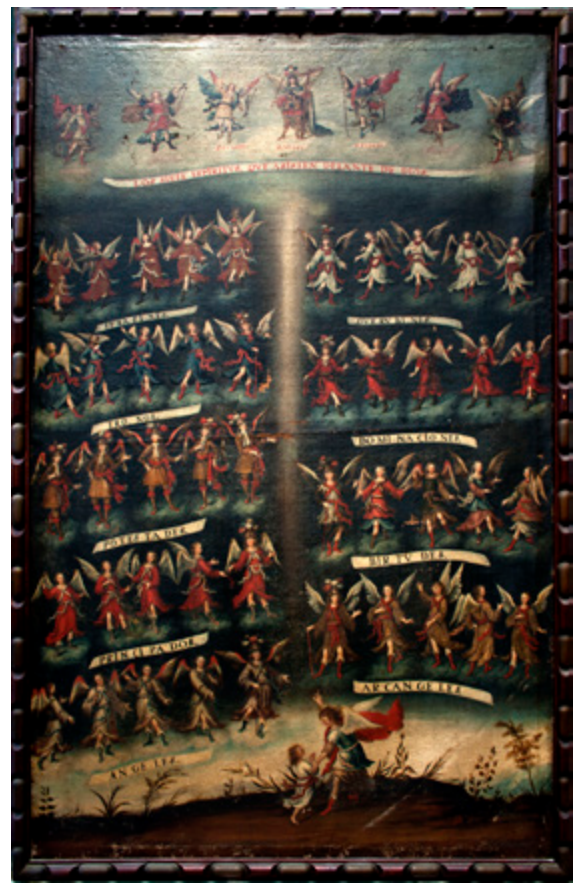

Figura 3. Anónimo, Jerarquía angélica con los Siete Arcángeles como principales, mediados del siglo XVIII, parroquia de San Nicolás de Bari (procedente de la iglesia de San Francisco), Sanlúcar de Barrameda, Cádiz.

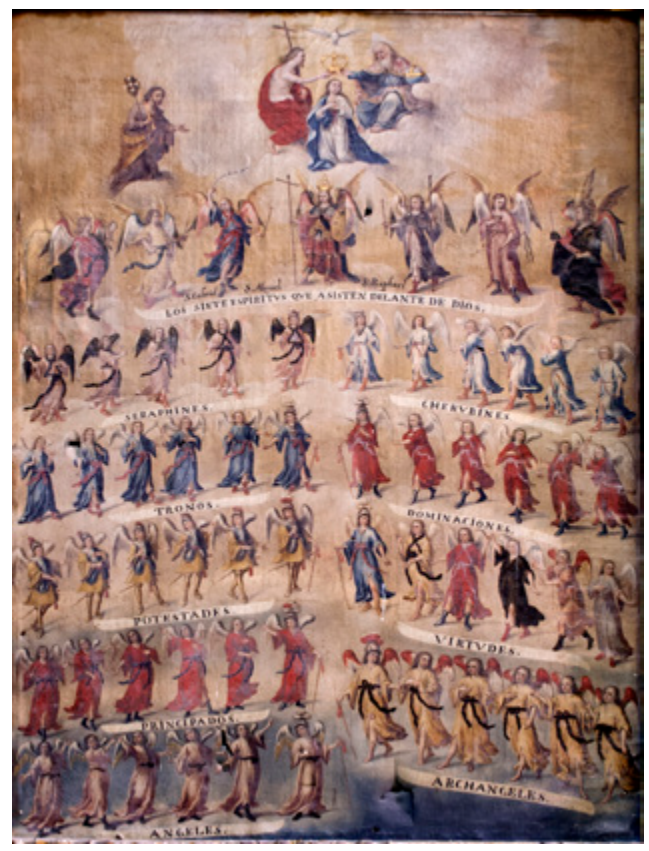

Figura 4. Anónimo, Jerarquía angélica con los Siete Arcángeles como principales, mediados del siglo XVIII, templo del convento de San Francisco, Lebrija, Sevilla. 


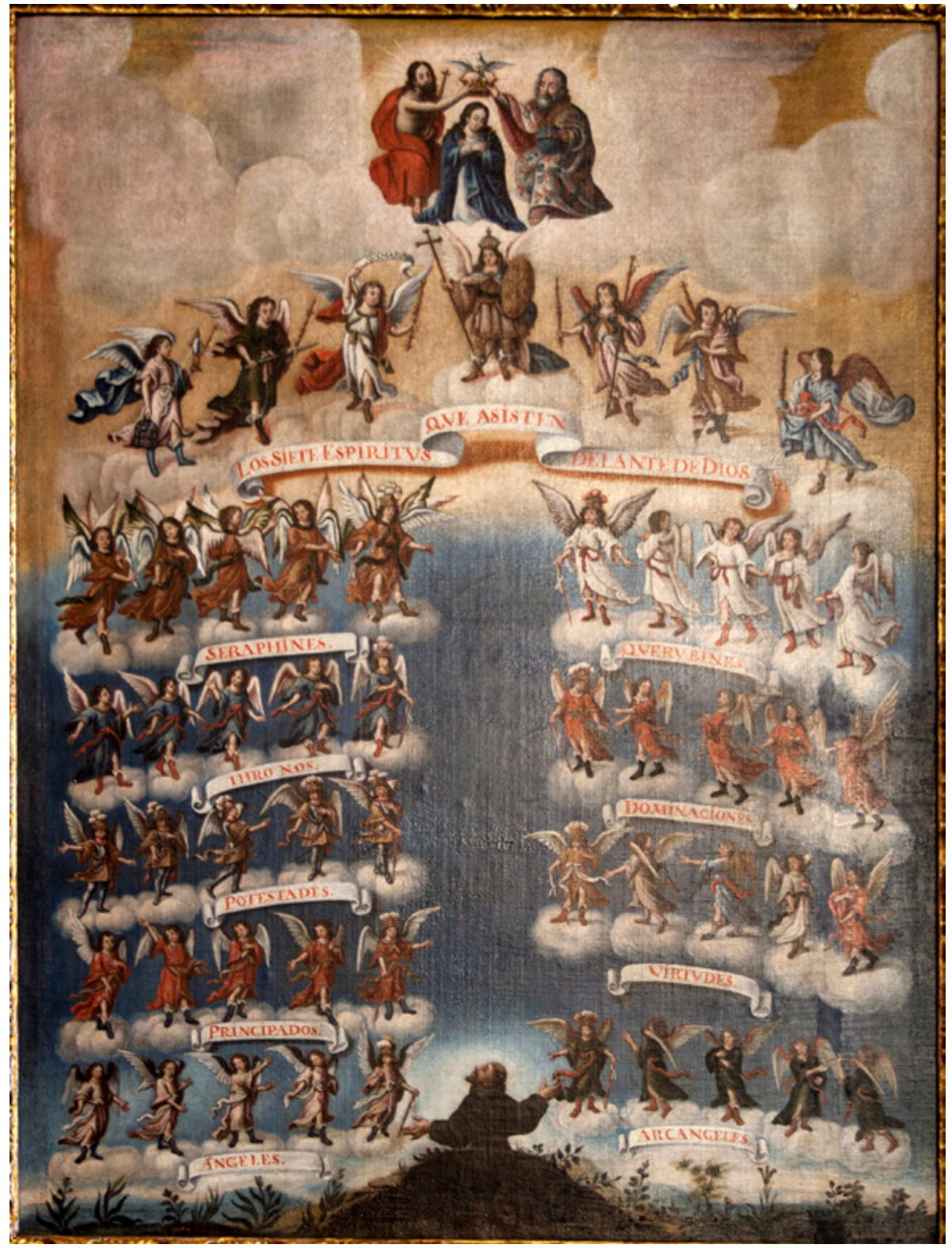

Figura 5. Anónimo, Jerarquía angélica con los Siete Arcángeles como principales, mediados del siglo XVIII, capilla de la Aurora, El Puerto de Santa María, Cádiz. 


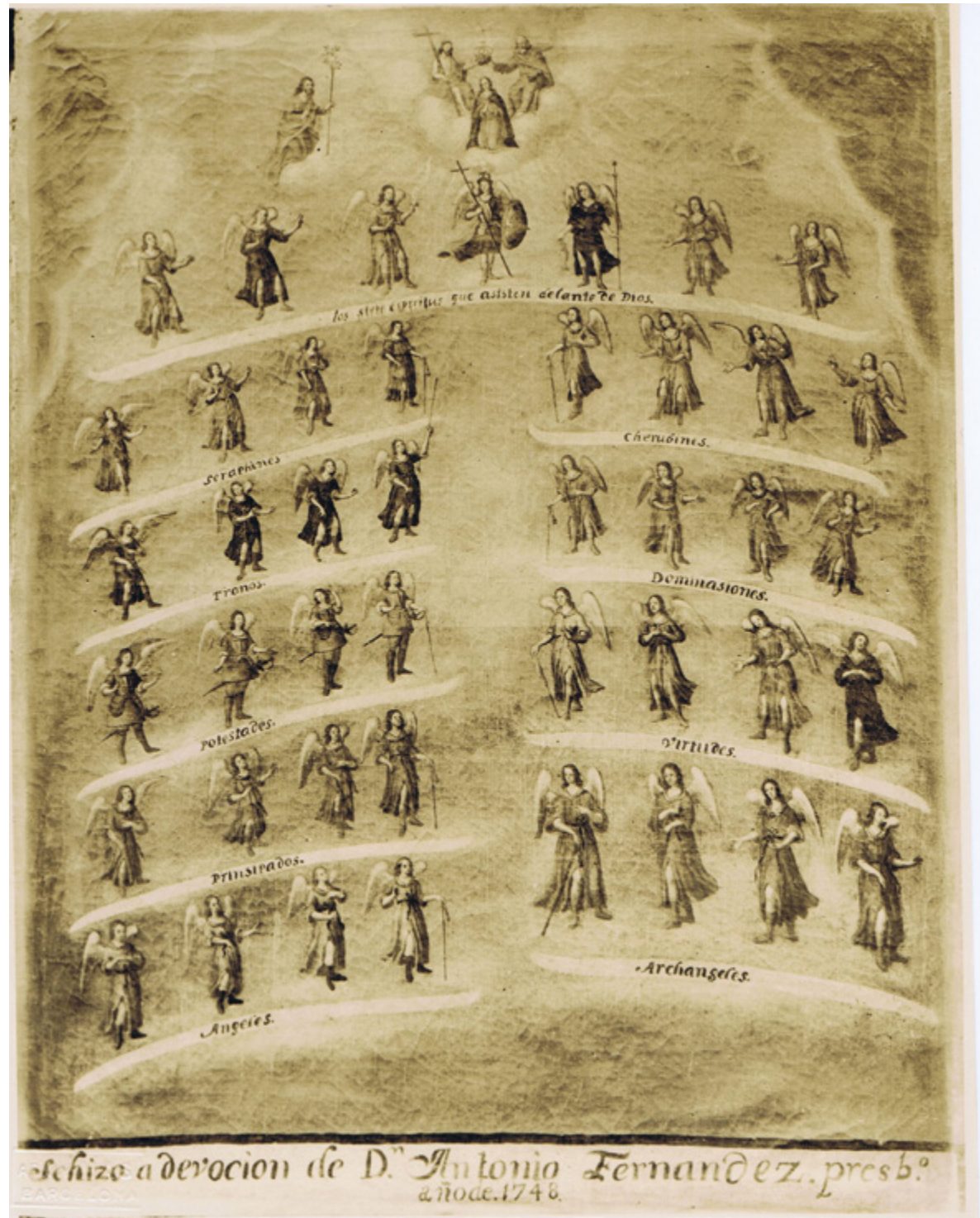

Figura 6. Anónimo, Jerarquía angélica con los Siete Arcángeles como principales, 1748, paradero desconocido (previamente, capilla de la Aurora, El Puerto de Santa María, Cádiz). 


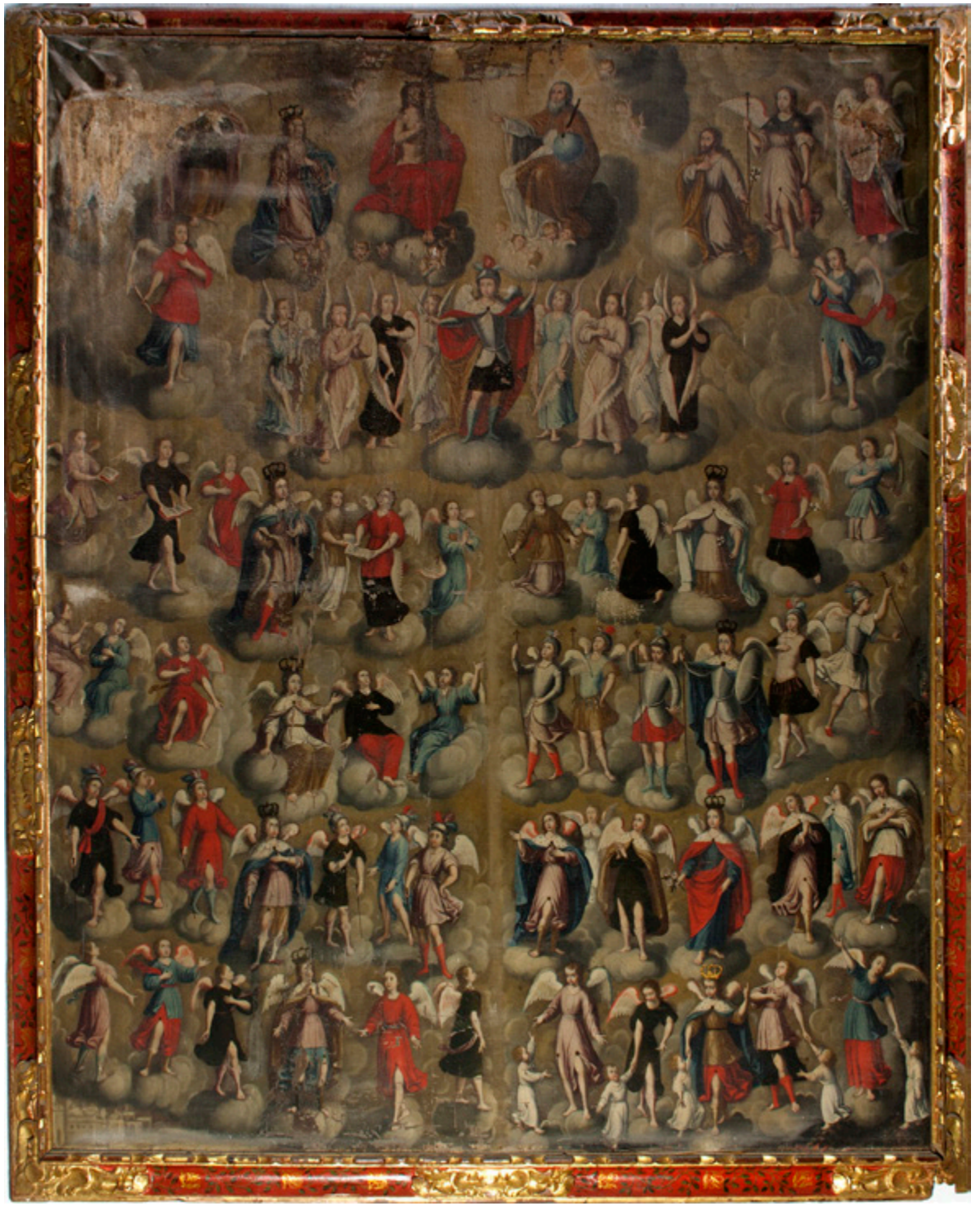

Figura 7. Anónimo, Jerarquía angélica con los Siete Arcángeles y la Trinidad, mediados del siglo XVIII, templo de San Francisco, Arcos de la Frontera, Cádiz. 


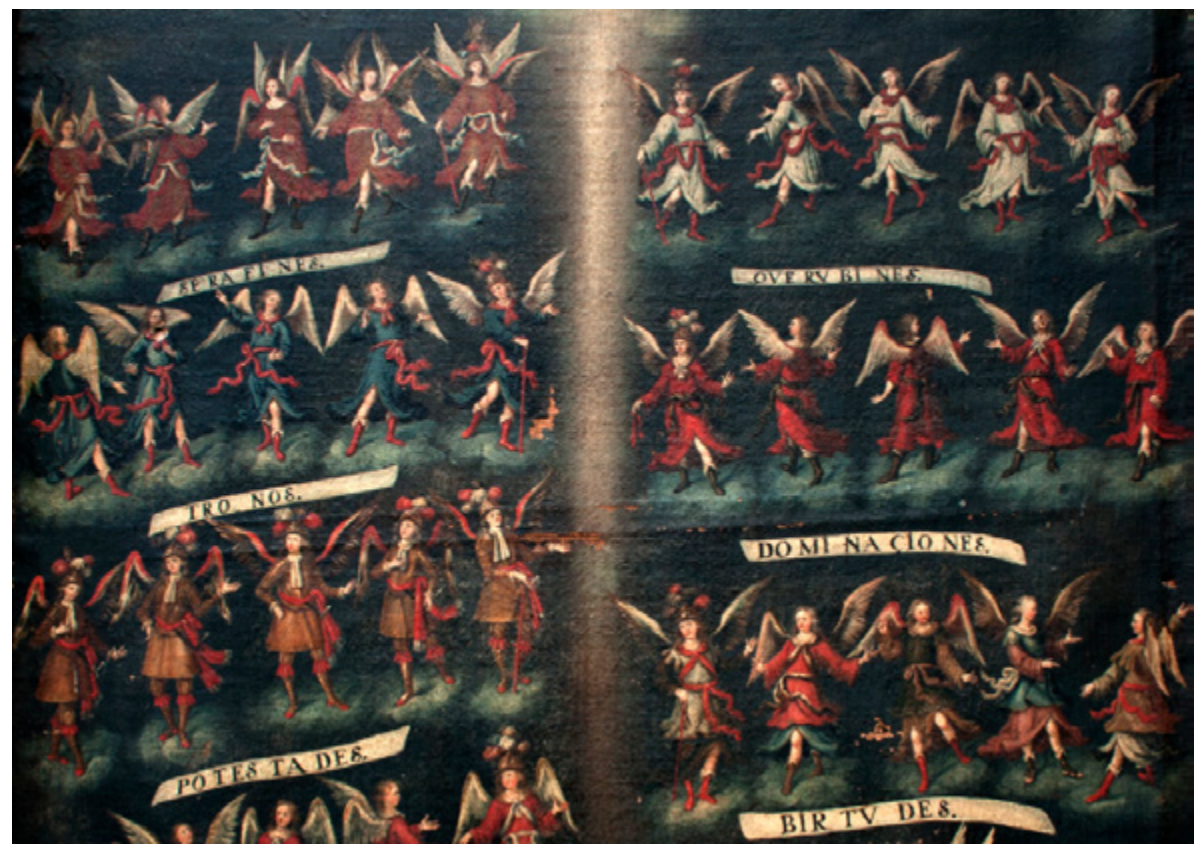

Figura 8. Anónimo, Jerarquía angélica con los Siete Arcángeles como principales (detalle), mediados del siglo XVIII, parroquia de San Nicolás de Bari (procedente de la iglesia de San Francisco), Sanlúcar de Barrameda, Cádiz. 